Systematic Botany (2020), 45(3): pp. 607-619

(c) Copyright 2020 by the American Society of Plant Taxonomists

DOI 10.1600/036364420X15935295449916

Date of publication August 11, 2020

\title{
A New Species of Randia (Rubiaceae) and the Taxonomic Significance of Foliar Anatomy in the Species of Randia of the Southern Cone of America
}

\author{
Marina D. Judkevich, ${ }^{1,4}$ Ana M. Gonzalez, ${ }^{1,2}$ and Roberto M. Salas ${ }^{1,3}$ \\ ${ }^{1}$ Instituto de Botánica del Nordeste, Universidad Nacional del Nordeste - Consejo Nacional de Investigaciones Científicas y \\ Técnicas, Sargento Cabral 2131, CP 3400, cc 209, Corrientes, Argentina \\ ${ }^{2}$ Facultad de Ciencias Agrarias, Universidad Nacional del Nordeste, Sargento Cabral 2131, CP 3400, cc 209, Corrientes, Argentina \\ ${ }^{3}$ Facultad de Ciencias Exactas y Naturales y Agrimensura, Universidad Nacional del Nordeste, Sargento Cabral 2131, CP 3400, cc \\ 209, Corrientes, Argentina \\ ${ }^{4}$ Author for correspondence (marina-judkevich@hotmail.com)
}

Communicating Editor: James I. Cohen

\begin{abstract}
Randia heteromera is a new species described based on studies of taxonomy and vegetative anatomy (leaf, stipule, and colleters). This species is illustrated and diagnosed in comparison to the other four similar species of Randia in the Southern Cone of America. The species grows in areas of humid forests, locally known as the humid Chaco in the southern part of its distribution (Argentina and Paraguay), and in seasonal forests in the northern part, in northeast Paraguay and the south of Mato Grosso do Sul in Brazil. We present a key to distinguish $R$. heteromera from the other species of the Southern Cone of America. The species was also compared with similar taxa, Randia nitida or R. hebecarpa, occasionally used to identify material from the Southern Cone of America. A distribution map is provided. The anatomical data studied had a taxonomic value at the species level. In addition, based on the leaf anatomy studies carried out in the present study and in previous studies, three new types of vascular tissue organization in the leaf are described for Rubiaceae.
\end{abstract}

Keywords-Colleters, Gardenieae, leaf structure.

Randia L. belongs to the tribe Gardenieae (Rubiaceae) and includes ca. 90 species of shrubs, trees, and lianas that inhabit evergreen and deciduous forests from sea level up to $3300 \mathrm{~m}$ (Lorence 1986; Gustafsson 1998, 2000). The genus can be distinguished by dioecy, brachyblasts with clustered stipules and leaves, pollen grains in permanent tetrads, and fruits with many discoid seeds embedded in a dark pulp (Gustafsson 2000; Judkevich et al. 2015, 2016).

The species of the genus Randia are difficult to identify. Currently, Randia armata (Sw.) DC. is the name most used for specimens from the Southern Cone of America, even though they are morphologically variable (e.g. Schumann 1889; Chodat and Hassler 1904; Smith and Downs 1956; Bernardi 1985; Serrano and Terán 1998; Jung-Mendaçoli and Araujo 2007; Bacigalupo et al. 2008; Ferreira and Santos Vieira 2015); sometimes cited as Randia spinosa (Jacq.) H. Karst., nom. illeg., or Basanacantha spinosa (Jacq.) K. Schum. Delprete et al. (2005) were the first to restrict the application of this name to plants from Central America, the Antilles, and northern South America, and to exclude the plants of Southern Cone of America from its circumscription.

The latest taxonomic treatments for the Southern Cone of America were provided by Judkevich et al. $(2015,2016)$, in which they recognized four species for this area: Randia brevituba Judkevich \& R.M. Salas, R. calycina Cham., Randia ferox (Cham. \& Schltdl.) DC., all from lowland forests in eastern Paraguay, northeast Argentina, and southern Brazil, and Randia micracantha (Lillo) Bacigalupo from seasonally dry piedmont forests in northwestern Argentina and the south of Bolivia. The authors also have accepted the exclusion of Randia armata from the Southern Cone of America, as already suggested by Delprete et al. (2005) and Delprete (2010), based on characters such as the form of the calyx and apex of the floral buds and the length and diameter of the corolla tube.

A few new species have been discovered in the genus Randia in South America in recent years, all of them supported by clear diagnostic traits, e.g. the pubescent style in $R$. pubystila C.Gust.; 1-florous staminate and pistillate inflorescences in R. wigginsii C.Gust. (Gustafsson 2000); broadly elliptic or obovate velutinous leaves and rotating calyx lobes in R. itatiaiae S.J.Silva Neto \& R.Avila (Silva Neto and Ávila 2007); and reflexed yellow corolla lobes and foliaceous calyx lobes in Randia brevituba (Judkevich et al. 2016). However, species complexes with similar morphological characteristics have not previously been addressed in depth. Despite advances made by some authors above mentioned, Randia armata represents one of the most difficult complexes to approach for any taxonomist who is new to the genus. Indeed, in different geographic regions or countries, new species or even validly published but poorly known species, probably remain masked in a heap of specimens identified as $R$. armata. Such is the case of the new species here described, which has been identified for a long time as $R$. armata or one of its synonyms (e.g. R. spinosa).

Anatomical analyses have been helpful in taxonomy and have been used effectively for a long time (Solereder 1908; Metcalfe and Chalk 1979). They can be useful to complement taxonomic studies in cases where the external morphological characters are not sufficient for differentiating between taxa, to establish approximate affinities of sterile herbarium specimens, or to show evolutionary trends among taxa (Metcalfe and Chalk 1950, 1979). According to Carlquist (1961), in the angiosperms the leaf is an organ with much anatomical variation, and these variations are generally in line with species, genera, or families. Dickison (1975) emphasized that the leaf characters that present systematic value are the cuticle (thickness and presence of ornamentations), the epidermis (number of epidermal layers, shape and size of epidermal cells, trichomes, stomata), the mesophyll (type of mesophyll, number of layers, shape, and distribution of their cells, presence of lacunar spaces, presence of crystals and secretory canals), the fibers (presence and distribution), and the vascular system (venation patterns, contour of vascular tissue, location and abundance of sclerenchyma).

In the Atlantic Forest species of Psychotria L. (Rubiaceae), the anatomy and micromorphology of the leaves of interspecific groups have been useful as diagnostic traits for the genus (Moraes et al. 2011). In Randia calycina, R. ferox, and 
R. micracantha, the distribution of vascular tissue in the middle vein of the leaf is a diagnostic character that, together with others, helps to differentiate these species (Judkevich et al. 2015).

With regard to the above, the aims of this paper are to: 1 ) describe the new species of Randia, taking into account morphological, anatomical and ecological observations and provide a key to distinguish $R$. heteromera from the other species from the Southern Cone of America; 2) compare and discuss the leaf anatomical characteristics of the new species with those already known for the other Randia species from the Southern Cone of America.

\section{Materials ANd Methods}

Taxonomy-Conventional taxonomic methods were followed. The following herbaria were consulted, including all main herbaria of the Southern Cone of America: AS, BM, CEN, CTES, CORD, CPAP, ESA, FCQ, FUEL, G, HUEFS, K, LIL, NY, MO, PY, RB, SF, SI, SP, UB, UEC, and UNR (acronyms according to Thiers 2020). We use the terms pistillate and staminate inflorescences/flowers instead of female and male respectively, according to Judkevich et al. (2016). Hence, the following abbreviations are used for each specimen in the Additional Specimens Examined: P (pistillate), $\mathrm{S}$ (staminate), fl (flower), and fr (fruit).

Morpho-Anatomy-Observations were made using fresh and fixed material of mature leaves and vegetative apexes fixed in FAA (formalin, acetic acid, ethanol 70\%, 90:5:5). For the study of the foliar anatomy, sections of the petiole, the middle portion of the blade including the margin and the apex were made. At least 5 organs from each specimen were cut and analyzed. The material used was from the following collections:

Randia heteromera. Argentina. -CORRIENTES: Dept., Riachuelo, 17 Sep 2014 (S, fl), M.D. Judkevich E R.M. Salas 55 (CTES); idem, 17 Sep 2014 (P, fl), M. D. Judkevich E R.M. Salas 56 (CTES); Idem, Puente Pexoa, 14 Sep 2016 (S, fl), M. D. Judkevich et al. 75 (CTES); idem, 14 Sep 2016 (P, fl), M. D. Judkevich et al. 77 (CTES). Dept. San Cosme, Las Lomas, Ensenada Grande, 29 Aug 2015 (S, fl), M. D. Judkevich et al. 61 (CTES); idem, 29 Aug 2015 (P, fl), M. D. Judkevich et al. 62 (CTES).

Randia brevituva. Argentina. -Misiones: Dept. San Ignacio,

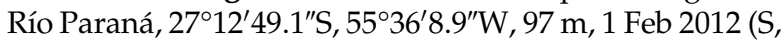
fl), H. Keller E N.G. Paredes 10686 (CTES); Establecimiento Pomera S.A., $27^{\circ} 13^{\prime} 20.5^{\prime \prime}$ S, 55 $34^{\prime} 41.4^{\prime \prime} \mathrm{W}$, 17 Sep 2014 (P, fl), H. Keller \& H. Franco 12258 (CTES).

For light microscopy (LM), the fixed material was dehydrated in graded ethanol-butanol series and embedded in paraffin according to Johansen (1940) modified by Gonzalez and Cristóbal (1997). The material was sectioned transversely and longitudinally using a rotary microtome (Microm International, Walldorf, Germany) at a thickness of $12 \mu \mathrm{m}$ (stipules) to 17-20 $\mu \mathrm{m}$ (leaves). The sections were stained with safranin Astra blue (Luque et al. 1996).

To confirm the presence of crystals in the tissues a microscope (Leica DM LV2) with polarized light was used. The observations and photographs were made with a stereoscopic microscope (Leica MZ 6) and a light microscope (Leica DM LV2).

For scanning electron microscopy (SEM), plant material was criticalpoint dried through a graded series of alcohol, mounted on stubs, coated with gold and observed using a JEOL LV 5800 scanning electronic microscope.

The epidermis was studied using sections of the leaf blade dissociated with sodium hypochlorite $50 \%$, washed with distilled water and stained with safranin. The classification of Metcalfe and Chalk (1950) was used to determine type of stomata. Also, stomatal density (number of stomata per $\mathrm{mm}^{2}$ ) was estimated.

Pollen-Samples of pollen were taken from mature anthers of fixed material (FAA) which were acetolized according to Erdtman (1966) and analysed by LM and SEM. An average of 25 pollen grains was measured. The terminology used follows Punt et al. (2007).

\section{TAXONOMic TREATMENT}

Randia heteromera Judkevich \& R. M. Salas, sp. nov. TYPE: Argentina. Corrientes: Dept. Capital, Riachuelo, sobre

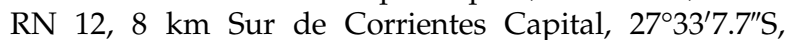
$58^{\circ} 45^{\prime} 7.75^{\prime \prime} \mathrm{W}, 51 \mathrm{~m}, 17$ Set 2014, M.D. Judkevich $\mathcal{E}$ R.M. Salas 56 (holotype: CTES; isotype: SI).

Although $R$. heteromera is similar to Randia ferox, it differs in having leaves without domatia (vs. leaves always with tuftdomatia), stipules with ciliate margins and caudate apex (vs. stipules with glabrous margins, acute apex, non-caudate), the length/width ratio of the corolla tube of $11.5-14.7 \times$ $2.1-2.8 \mathrm{~mm}$ in staminate flowers and $10.6-14.4 \times 2.1-3.1 \mathrm{~mm}$ in pistillate flowers (vs. length/width ratio of corolla 22.6-23.0 $\times 2.5-4.0 \mathrm{~mm}$ in staminate flowers and 23.5-25.0 $\times$ 4.0-5.0 $\mathrm{mm}$ in pistillate flowers), calyx lobes with ciliate margins (vs. calyx lobes with glabrous margins) and fruit 2.4-2.7 cm long, obovoid or globose, with a pedicel $4-7 \mathrm{~mm}$ long, pericarp 0.8-1.0 mm thick, (vs. fruit 3-5.2 cm long, commonly ovoid, obovoid or ellipsoidal, rarely subglobose, sessile, pericarp 1.2-4 mm thick).

Tree, treelet, or shrub, 0.8-4(-6) $\mathrm{m}$ tall, diameter at breast height 1-11 cm, showing vegetative reproduction by rhizomes, dioecious; branches opposite with 3-4 spines per node, concolorous greyish, glabrous. Stipules imbricate and forming a cap over the shoot apex, deciduous after the fourth or fifth node, 3.5-6.4 × 2.4-5.2 mm, margin ciliate, externally puberulous, internally with colleters and simple trichomes at the base, with acute or acuminate apex, generally mucronate, margins ciliate. Leaves pseudopetiolate; pseudopetiole 0.5-12.6 mm long, puberulous; blades elliptic, ovate or obovate, sometimes reduced and then almost orbicular or irregularly circular, $35.9-70.0 \times 18.8-38.3 \mathrm{~mm}$, glabrous or puberulous on both leaf surfaces, veins glabrous on adaxial surface and puberulous to pubescent on abaxial surface; discolorous primary and secondary veins, 6-9 secondary veins on each side of the middle vein, ascendant, secondary and tertiary veins scarcely visible abaxially; apex generally mucronate, mucron sometimes spinescent, base acute. Inflorescences terminal, sessile, fasciculate; the staminate ones 3-8flowered, the pistillate ones 1-flowered; bracts foliaceous, $25-50 \times 15-35 \mathrm{~mm}$, glabrous or puberulous, veins glabrous, puberulous to pubescent, bracteoles absent. Flowers fragrant; (4-)5(-7)-merous. Staminate flowers 10.8-21.4 mm long, pedicellate; pedicel 1.6-6.7 mm long; calyx (4-)5(-7)-lobed, lobes ovate, equal, 3.1-5.9 $\times 1.4-2.6 \mathrm{~mm}$, glabrous on both surfaces, without colleters, with ciliate margins; calyx tube very short, between the calyx lobes and the ovary, glabrous on both surfaces; corolla salverform, corolla tube 11.5-14.7 $\times$ 2.1-2.8 mm, green, externally glabrous, internally puberulous from the middle of the tube to the base of the corolla lobes; lobes obovate, 6.6-11.1 × 5.9-9.0 mm, white, apex rounded, margins slightly undulate; ovary obconic, glabrous to puberulous; stamens partially exserted, anthers sessile, 4.5-5.2 mm long, connective generally apiculate; pollen in permanent tetrads, tetrahedral and decussate; tetrads with isolated symmetrical grains, triporate, pores circular; exine psilate to foveolate, especially near the pores; style partially exserted, glabrous; stigma partially exserted, bilobed, the lobes ovoid. Pistillate flowers 20.3-29.0 mm long., shortly pedicellate; pedicel 0.9-2.7 mm long; calyx 5-lobed; lobes ovate, equal, glabrous on both faces, without colleters, with margins ciliate; calyx tube very short, between the calyx lobes and the ovary, 
glabrous on both surfaces; corolla salverform; corolla tube green, $10.6-14.4 \times 2.1-3.1 \mathrm{~mm}$, externally glabrous or puberulous, internally puberulous from the middle of the tube to the base of the corolla lobes; lobes white, obovate, apex rounded, margins lightly undulated, $6.6-9.3 \times 5.5-8.1 \mathrm{~mm}$; stamens partially exserted, sessile; anthers $1.8-2.8 \mathrm{~mm}$ long; ovary urceolate, glabrous to puberulous, 8.2-10.3 $\times$ $3.5-4.3 \mathrm{~mm}$; style partially exserted, glabrous; stigma 2-lobed, lobes ovate. Fruits obovoid or globose, yellow when ripe, 22.0-27.4 $\times 14.8-17.2 \mathrm{~mm}$, glabrous to puberulous, with pedicels of $4-7 \mathrm{~mm}$ long, nectary disk persistent in the fruit; pericarp $0.8-1 \mathrm{~mm}$ thick, coriaceous; seeds obovate in outline, discoid, 7.1-8.8 $\mathrm{mm}$ long, blackish, immersed in pulp. Figures 1, 2.

Distribution and Habitat-The species is found in Argentina, Paraguay, and Brazil (Fig. 3). In Argentina, the species grows in northwest Corrientes (Dept. Berón de Astrada, Capital, Concepción, General Paz, Itatí, Mburucuyá, Saladas, San Cosme, and San Luis del Palmar), eastern Chaco (Dept. General Paz and Primero de Mayo), Formosa (Dept. Formosa, Pilagá, Pilcomayo, and Pirané), Misiones (Dept. Posadas) and Santa Fe (Dept. General Obligado). In Paraguay, it occurs in the Dept. Amambay, Central, Concepción, Cordillera, Neembucú, Paraguarí, and Presidente Hayes. In Brazil, the species grows in Mato Grosso do Sul, with the northernmost collection point in the municipality of Corumbá.

Randia heteromera grows in seasonally humid forests along the main rivers of the region, Paraguay and Paraná, and some of their tributaries. The species inhabits inside, in gaps, and especially on the edge of the forest. Inside forests, it grows as small trees up to $6 \mathrm{~m}$ tall (diameter at breast height $5-11 \mathrm{~cm}$ ), as part of the lower forest stratum. In the margin or in gaps, it was observed flowering as a shrub from $0.8 \mathrm{~m}$ to treelets $2 \mathrm{~m}$ tall. These forests are mostly located on low sandhills (from ancient riverbanks), which are exceptionally, or never, inundated. They occur at altitudes between 54 and $280 \mathrm{~m}$. The main woody components of these forests are Anadenanthera colubrina (Vell.) Brenan, Calycophyllum multiflorum Griseb., Cordia americana (L.) Gottschling \& J.S. Mill., Enterolobium contortisiliquum (Vell.) Morong, Gleditsia amorphoides (Griseb.) Taub., Handroanthus heptaphyllus (Vell.) Mattos, Hexachlamys edulis (O. Berg) Kausel \& D. Legrand, and Myracrodruon urundeuva Allemão. A few collections came from forests of Schinopsis balansae Engl., a vegetation typical for the Chaco biome, but always near to water bodies or seasonally flooded. According to the biogeographic models proposed by Morrone (2017) for the Neotropics, Randia heteromera is distributed entirely in the biogeographic province of Chaco, especially in the area known as the humid Chaco. Following the regionalization proposed by Prado (1993), all specimens are from the Austro-Brazilian Transitional Forest, typically represented by the trees listed above.

Additionally, Randia heteromera seems to be a pioneer species, both in wooded or open habitats (grassland or savannas). In northeast Paraguay (Amambay), the species also behaves like an invasive plant in open environments, having a reduced, much-branched habit (up to $1 \mathrm{~m}$ tall) and forming dense populations that impede the passage of persons or animals due to its abundant thorny branches. Through this growth form, the species could be an important source of natural regeneration, especially relevant being its ecological evaluation as a probable nurse plant of trees and palm seedlings. In this sense, $R$. heteromera was mentioned (as R. armata), in the Paraguayan
Chaco, as a very abundant element in dense fragments of forest surrounding the palm Copernicia alba Morong. In these forests, palm seedlings and other woody plants are protected from intensive cattle and goat foraging (Degen and Negrelle 2014).

Phenology - This species flowers from July to October and bears fruits throughout the year. At the end of winter, the species has profuse blooms and abundant mature fruits at the same time.

Etymology-The specific epithet refers to the variation in the number of corolla lobes. The normal number of lobes is 5 , but 4-6-7-merous corollas are commonly found on the same plant (Fig. 2G-J).

Taxonomic Notes-The specimens of Randia heteromera were erroneously identified as $R$. armata (and its numerous synonyms, see Taylor and Lorence 1993), R. calycina, R. ferox, $R$. hebecarpa Benth., and R. nitida (Kunth) DC. in all herbaria consulted. Randia heteromera differs from $R$. armata by the apex of the floral bud being ovoid and obtuse (vs. narrowly piriform), the diameter of the corolla tube 2.1-3.1 mm (vs. ca. $1 \mathrm{~mm}$ ) and the ovate calyx lobes (versus narrowly elliptic). In the Southern Cone of America, the most similar species is $R$. ferox, which differs from $R$. heteromera by being a tree $4-12 \mathrm{~m}$ tall, rarely shorter, with longer corolla tubes [22-34 (S), 25-27 (P) $\mathrm{mm}$ long], and larger fruits $(30-50 \times 25-30 \mathrm{~mm})$, and a pericarp that is thickened and fleshy when fresh and ligneous and thickened when dry (pericarp 1.2-3.5 mm thick). Additionally, the new species shares the length of the flowers and the presence of pedicellate fruits with $R$. calycina, but in all specimens analyzed of the latter the flowers are externally pubescent and the fruit surface bears lenticels. In the other species of the Southern Cone of America, the fruits are always subsessile or sessile, varying from glabrous in $R$. brevituba, $R$. calycina, and R. ferox to pubescent in R. micracantha. Randia heteromera also differs from the other species in the Southern Cone of America by having stipules and calyx lobes with conspicuously ciliate margins (Fig. 1D).

The exine of the pollen grains differs from that observed in other species in the Southern Cone of America; it is psilate in $R$. brevituba and R. ferox, psilate to foveolate in R. calycina, and reticulate in R. micracantha.

Outside of the Southern Cone of America, Randia heteromera is morphologically similar to Randia nitida (type from Colombia, Bonpland 1460) in having glabrous leaves, discolorous primary and secondary veins, relatively small flowers, with a glabrous calyx and corolla. Randia nitida differs by the secondary and tertiary veins of the leaves being prominent on both faces in dry material (vs. secondary and tertiary veins scarcely visible abaxially) and by the length of the calyx lobes [2.4-2.9 $\mathrm{mm}(\mathrm{S})$ vs. 3.1-5.9 $\mathrm{mm}$ long (S)] and corolla tube [7.0-10.0 mm long (S) vs. $11.5-14.7 \mathrm{~mm}$ long (S)]. Some materials examined were also identified as $R$. hebecarpa (type from Guyana, Schomburgk 775), however R. heteromera can easily be distinguished by the concolorous greyish spines, glabrous or puberulous leaves and discolorous veins, glabrous ovary and calyx lobes (vs. discolorous blackish spines, pubescent leaves and concolorous veins, tomentose ovary and calyx lobes).

Additional Specimens Examined-Argentina.- Снасо: Dept. Primero de Mayo, Colonia Benítez, en bosque, 16 Mar 1930 (P, fr), A. G. Schulz 12 (CTES, SI); idem, bosque ribera del Río Tragadero, Jun 1932 (P, fr), A. G. Schulz 501 (CTES); idem, Sep 1938 (S, fl), A. G. Schulz 9723 (CTES); idem, 28 Sep 1965 (S, fl), A. G. Schulz 15196 (CTES); idem, Jun 1970 (P, fr), P. Insfrán 149 (CTES); idem, Reserva INTA, 26 Sep 1945 (S, fl), A. G. Schulz 


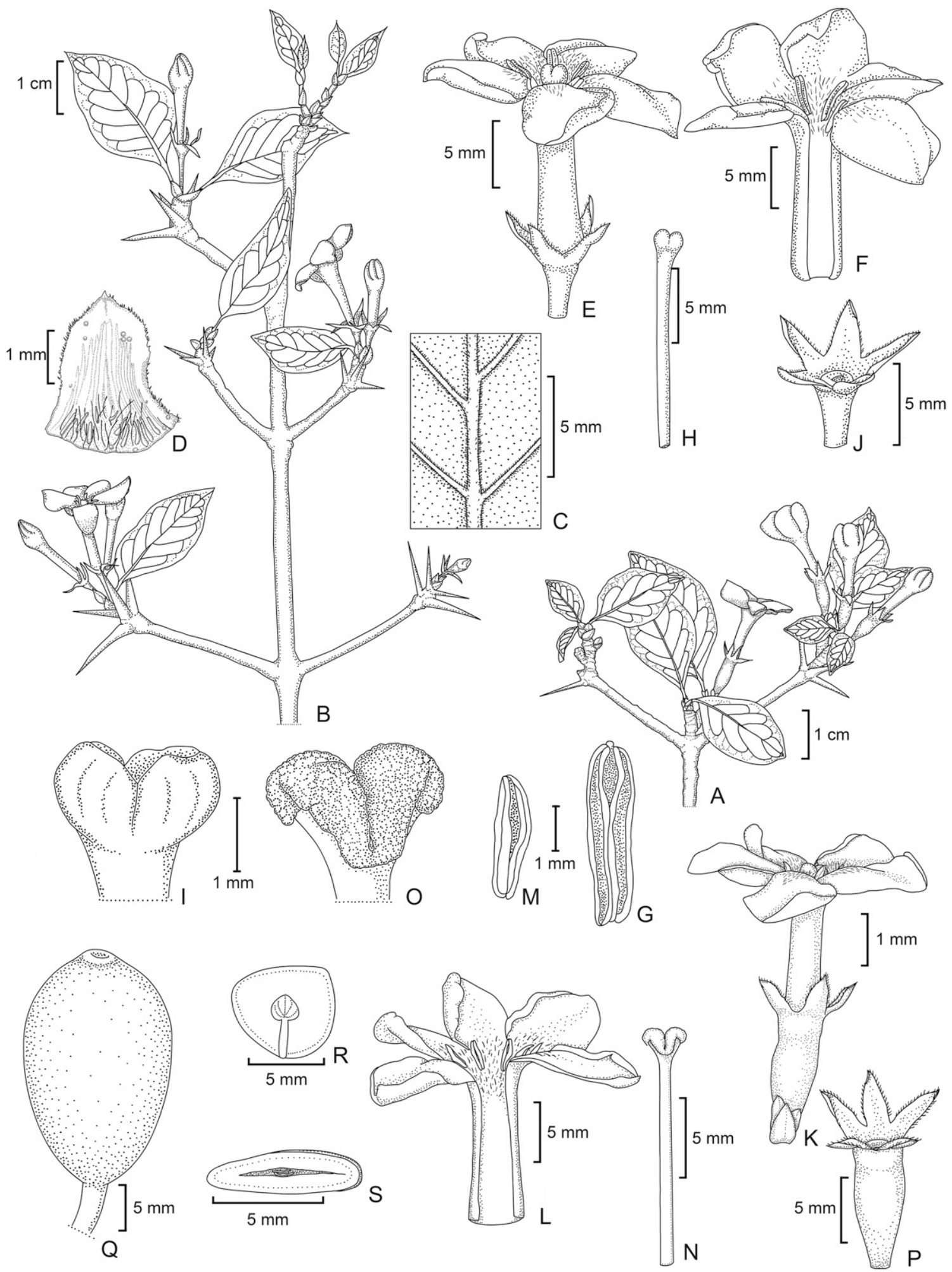

FIG. 1. Randia heteromera. A. Branch with pistillate flowers. B. Branch with staminate flowers. C. Detail of the abaxial face of a leaf. D. Detail of the inner face of the stipule with colleters and trichomes present at the base. E-J. Staminate flower. E. Complete flower. F. Corolla unfolded. G. Anther. H. Style and stigma. I. Detail of stigma. J. Detail of reduced ovary, calyx, and nectar disc. K-P. Pistillate flower. K. Complete flower. L. Corolla unfolded. M. Sterile anther. N. Style and stigma. O. Detail of stigma. P. Detail of ovary, calyx, and nectary. Q. Ripe fruit. R. Seed in longitudinal section. S. Seed in cross section. Illustration: Marina D. Judkevich. A, K-P from Judkevich et al. 68; B-J from Judkevich et al. 67.

6360 (CTES); idem, Reserva INTA, sobre laguna, 24 Sep 1964 (S, fl), A. G. Schulz 13995 (CTES); idem, Reserva INTA, 24 Sep 1964 (S, fl), A. G. Schulz 19995 (CTES); idem, Margarita Belén, La Loma, 30 Aug 1942 (S, fl), A. G. Schulz 3486 (CTES, LIL); idem, 14 Oct 1946 (P, fr), R. Aguilar 915
(CTES, LIL). - CoRRIENTES: Dept. Berón de Astrada, $46 \mathrm{Km}$ W de Itá Ybaté, Valencia, en selva, 15 Jan 1977 (P, fr), A. Schinini 13984 (CTES). Dept. Capital, RN 12, 20 Km de Corrientes, "Granja Yatay", 22 Jan 1976 (P, fr), A. Schinini 12512 (CTES); idem, 5 Km E de Laguna Brava, 6 Sep 1970 (S, fl), 

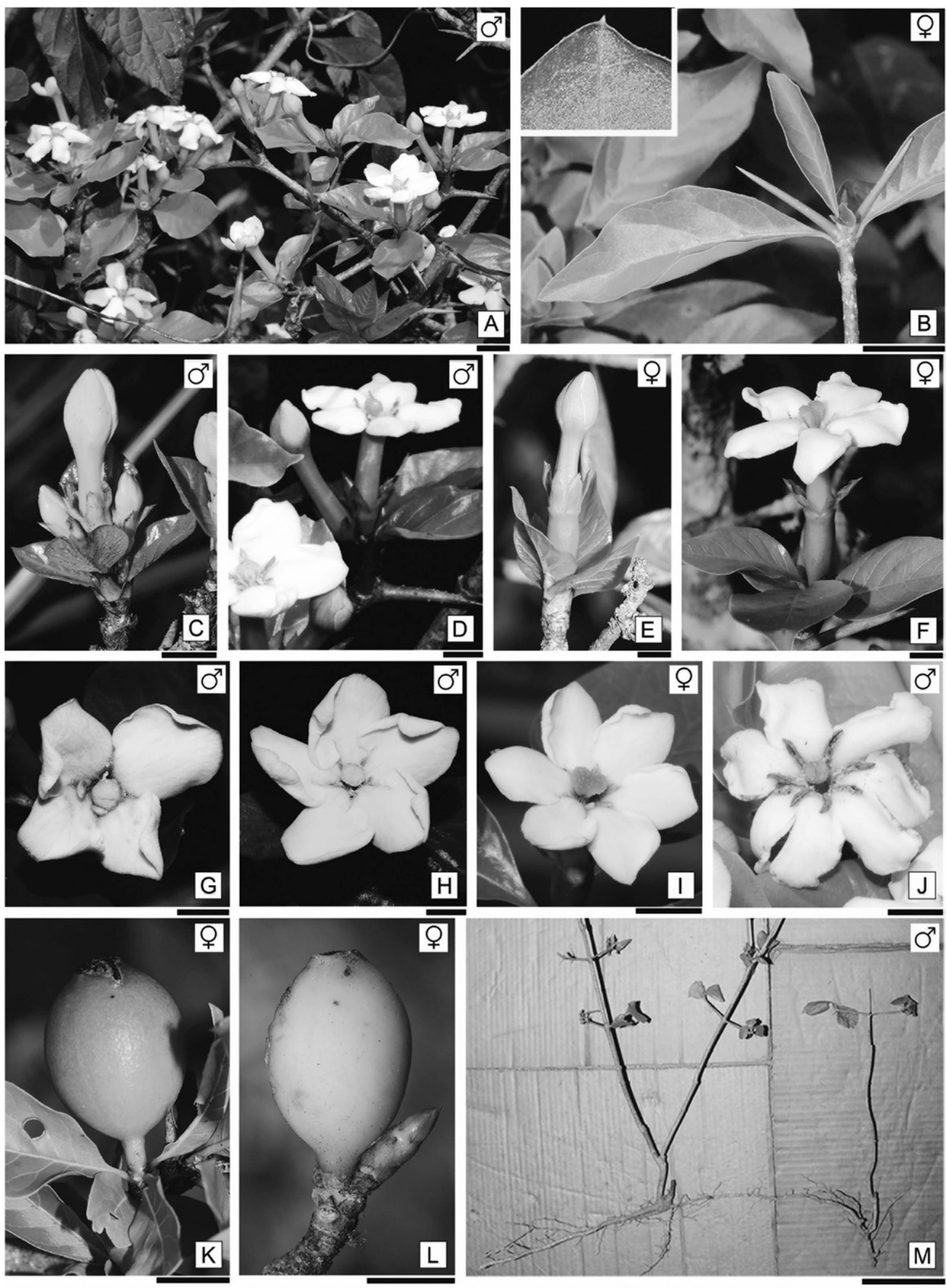

FIG. 2. Randia heteromera. A. Flowering branches. B. Foliar node with leaves, stipules, and thorns; above, detail of the mucronate apex of the leaf. C. Staminate flower bud. D. Staminate flower. E. Pistilate flower bud. F. Pistilate flower. G. Corolla 4-merous. H. Corolla 5-merous. I. Corolla 6-merous. J. Corolla 7-merous. K. Immature fruit. L. Mature fruit. M. Young plants connected by a rhizome. Scales: A-B, $\mathrm{K}-\mathrm{L}=1 \mathrm{~cm} ; \mathrm{C}-\mathrm{J}=5 \mathrm{~mm} ; \mathrm{M}=10 \mathrm{~cm}$.

A. Krapovickas \& C. L. Cristóbal 15849 (CTES); idem, Riachuelo, 16 Sep 1973 (S, fl), C. L. Cristóbal \& A. Schinini 1083 (CTES); idem, borde de arroyo, 16 Oct 1986 (P, fl), E. L. Cabral 491 (CTES); idem, $10 \mathrm{Km}$ SE de Corrientes, 1 Km

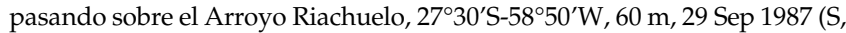
fl), C. Cristóbal \& A. Schinini 59461 (CTES, MO); 17 Sep 2014 (S, fl), M. D. Judkevich \& R. M. Salas 55 (CTES); idem, 17 Sep 2014(P, fl), Idem, Puente Pexoa, 14 Sep 2016 (S, fl), M.D. Judkevich et al. 75 (CTES); idem, 14
Sep 2016 (P, fl), M. D. Judkevich et al. 77 (CTES). Dept. Concepción, Tabay, 28 Mar 1975 (P, fr), M.M. Arbo et al. 968 (CTES); idem, 11 Km NW de Santa Rosa, borde isleta de selva, 14 Dec 1977 (P, fr), S.G. Tressens et al. 849 (CTES); General Paz, Capillitas, 29 Sep 1965 (fl, P), T.M. Pedersen 7054 (CTES, SI); Itá Ibaté, 12 Oct 1949 (S, fl), G. J. Schwarz 8214 (CTES, LIL). Dept. Itatí, RN 12, $21 \mathrm{Km}$ del desvío a Itatí, en selva marginal del Río Paraná, 17 Feb 1983 (P, fr), A. Schinini \& R. Carnevali 23284 (CTES); idem, La Palmira, 17 Feb 1983 


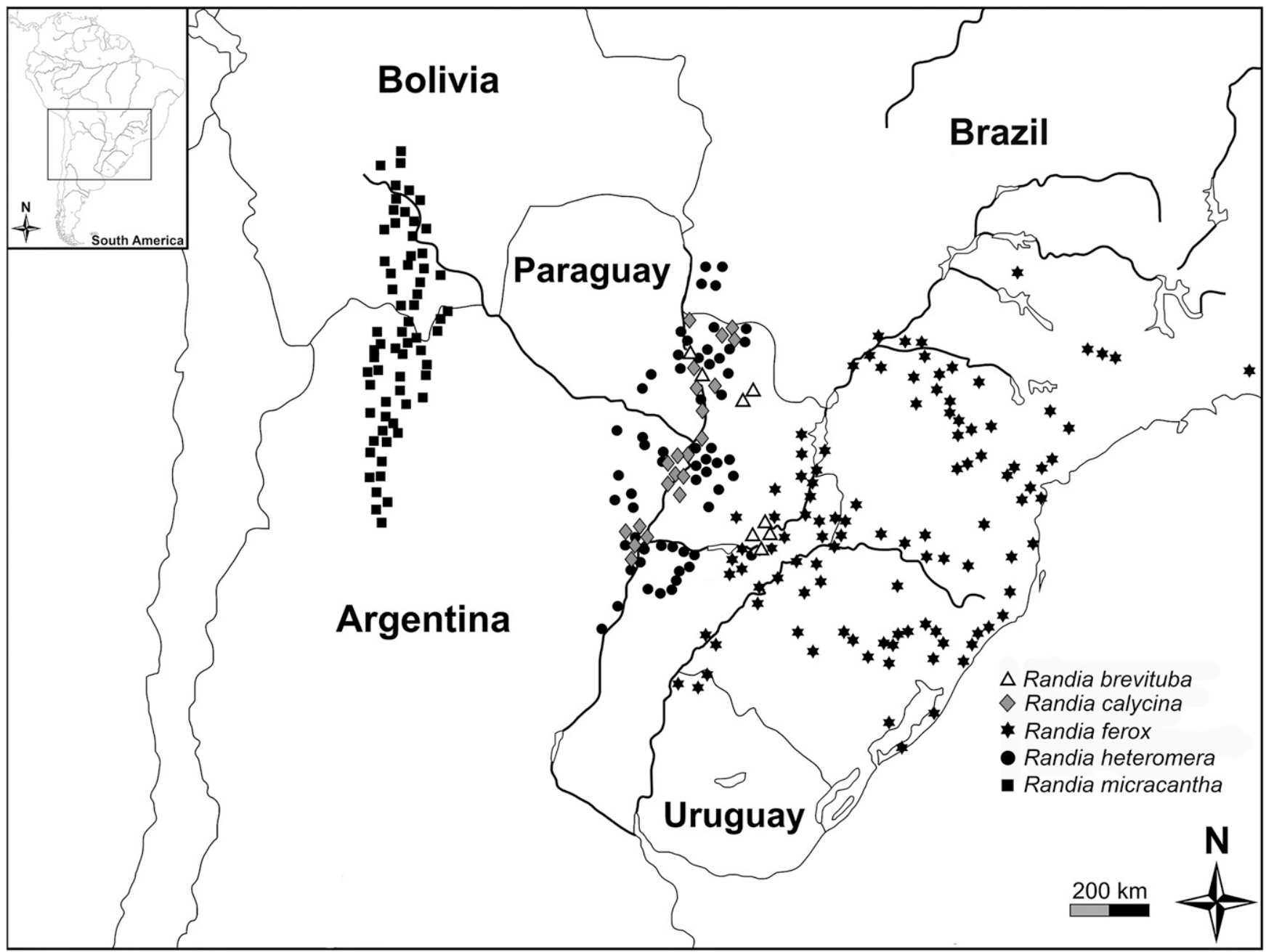

FIG. 3. Geographical distribution of species of Randia in the Southern Cone of America.

(P, fr), R. Carnevali 6039 (CTES). Dept. Mburucuyá, Estancia Santa Teresa, 5 Jun 1954 (P, fr), R. Carnevali 324 (CTES). Dept. Saladas, Pago de los Deseos, 2 Dec 1949 (P, fr), G. J. Schwarz 8956 (CTES, LIL). Dept. San Cosme, Río Paraná y Arroyo San Juan, orilla de monte, 25 May 1975 (P, fr), A. Schinini $\mathcal{E}$ C. Quarín 11523 (CTES); idem, Las Lomas, Ensenada Grande, 29 Aug 2015 (S, fl), M. D. Judkevich et al. 61 (CTES); idem, 29 Aug 2015 (P, fl), M. D. Judkevich et al. 62 (CTES); idem, Paso de la Patria, camino a Puerto González, 16 May 1967 (P, fr), A. Krapovickas \& C. L. Cristóbal 13110 (CTES); idem, $5 \mathrm{Km}$ E del camino a Paso de la Patria, 6 Jan 1966 (P, fr), A. Krapovickas E C. L. Cristóbal 11881 (CTES); idem, camino a Paso de la Patria, barrancas del Paraná, 30 Oct 1966 (fr), A. Burkart 26619 (SI); idem, desvío a Puerto González, 9 Km del cruce con camino a Paso de la Patria, 19 Sep 1971 (S, fl), S. G. Tressens et al. 192 (CTES). Dept. San Luis del Palmar, $10 \mathrm{Km}$ SE de San Luis del Palmar, Ruta 6, 26 Sep 1973 (S, fl), C. Quarin \& S. G. Tressens 1341 (CTES). -Formosa: Dept. Formosa, Estancia El Ombú, $26^{\circ} 4^{\prime} 22^{\prime \prime} \mathrm{S}$, $58^{\circ} 48^{\prime} 16^{\prime \prime} \mathrm{W}, 17$ Dic 2004 (fr), H. Maturo \& D. Prado 229 (BM, CTES, FCQ, G, MO, SI, UNR). Dept. Laishi, San Francisco de Laishi, Reserva El Bagual, 8 Sep 1996 (S, fl), A. Digiacomo 268a (CTES); idem, Villar Escobar, campo de Insfrán, margen del Río Bermejo, 26 28 $8^{\prime} 12^{\prime \prime} \mathrm{S}, 58^{\circ} 52^{\prime} 53^{\prime \prime} \mathrm{W}, 72 \mathrm{~m}$, 18 Oct 2011 (S, fl), S.A. Contreras \& A. Lutz 31 (CTES). Dept. Patiño, El Cogoik, 19 Feb 2004 (P, fr), S.G. Tressens et al. 6892 (CTES). Dept. Pilagá, 4 km E de Espinillo, 1 Jun 1949 (P, fr), I. Morel 7815 (CTES, LIL); Espinillo, 16 Feb 1949 (P, fr), I. Morel 7195 (CTES). Dept. Pilcomayo, Mercado Cui, 12 Nov 1986 (S, fl), Vargas s.n. (CTES0124765); idem, 12 km SW de Filipina, Estancia Salaberry, 18 Nov 1949 (S, fl), I. Morel 8904 (CTES, LIL). Dept. Pirané, Pirané, 13 km SW Estancia Ferrocarril Los Matacos, 28 Oct 1981 (S, fr), A.O. Bordón s.n. (CTES0415534); idem, El Colorado, Jun 1971 (P, fr), P. Insfrán 778 (CTES). MisIones: Dept. Capital, Posadas, 22 Apr 1945 (P, fr), M. Bertoni 1317 (CTES, LIL). SANTA FE: Dept. General Obligado, NE de Villa Guillermina, 15 Oct 1995 (S, fl), L. Zanuttini 38 (CTES, SF). Brazil. - Mato Grosso do Sul: Mun. Corumbá, Povoado do Amolar, RPPN Eliezér Batista,
Floresta con Acrocomia aculeata, 28 Dec 2010 (P, fr), R. Borges 1021 (CEN; RB); idem, Fazenda Coqueiro, Estrada M.S para forte Coimbra a $20 \mathrm{Km}$ da BR 262, jacadigo, 14 Dec 1986 (P, fr), C.N. Cunha et al. 2121 (CPAP, UEC). Mun. Miranda, 11 Apr 2004 (P, fr), G.O. Romão et al. 1075 (ESA, HUEFS, SP, UB); idem, 11 Apr 2004 (P, fr), G.O. Romão et al. 1073 (CEN, FUEL, SP); Mun. Tres Lagoas, Fazenda Rodeio, 20 ${ }^{\circ} 47^{\prime} 21^{\prime \prime}$ S, 51 ${ }^{\circ} 48^{\prime} 06^{\prime \prime} \mathrm{W}, 350$ m, 04 Feb 2016 (P, fr), G. Pereira-Silva 16726 (CEN); Parque Estadual das Várzeas do Rio Ivinhema [Taquarussu, Jateí and Naviraí municipalities], 12 Oct 2006, Z. V. Pereira et al. 1640 (UEC). Paraguay. - АмамвAY: Bella Vista, Río Apa y Arroyo Estrella, 25 Aug 1980 (S, fl), A. Schinini \& E. Bordas 20685 (CTES); idem, Cerro Corá, en selva marginal del Río Aquidabán, 21 Aug 1980 (S, fl), A. Schinini \& E. Bordas 20299 (CTES). - CENTRAL, Lago Ypacaraí, a orillas del bosque, sin fecha, (P, fr), N. Soria 1843 (CTES); idem, Emboscada, afloramientos rocosos, Dec 1979 (S, fl), A. Schinini 4170 (CTES); Tobatí, Ybitú Silla, Southern area, forest on slopes fancing south, $25^{\circ} 12^{\prime} \mathrm{S}, 57^{\circ} 07^{\prime} \mathrm{W}, 9 \mathrm{Mar}$ 1991 (P, fr), E. Zardini \& U. Velázquez 26993 (FCQ, MO). - CONCEPCIÓN, 1 Km

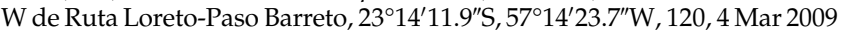
(P, fr), H.A. Keller et al. 6607 (CTES, SI); Estancia Bello Horizonte, tall forest and savanna on limestones, $22^{\circ} 47^{\prime} 50^{\prime \prime} \mathrm{S}, 57^{\circ} 25^{\prime} 31^{\prime \prime} \mathrm{W}, 150 \mathrm{~m}, 29$ Jan 1994 (S, fl), E. Zardini \& L. Guerrero 39682 (AS, MO); Estancia Santa María, $1 \mathrm{Km} \mathrm{S}$ of administration, gallery forest, $22^{\circ} 44^{\prime} \mathrm{S}, 57^{\circ} 28^{\prime} \mathrm{W}, 16$ Mar 1994 (P, fr), E. Zardini \& L. Guerrero 38808 (AS, MO); $2 \mathrm{Km} \mathrm{N}$ of Arroyo TagatiyáGuazú, savanna woodland on limestones, $22^{\circ} 46^{\prime} \mathrm{S}, 5^{\circ} 26^{\prime} \mathrm{W}$, 15 Mar 1994 (P, fr), E. Zardini \& T. Tilleria 38711 (AS, MO); in glareosis siccis prope Concepcion, Sep 1901-1902 (S, fl), E. Hassler 7313 (G00229794). -Cordillera, Cerro Caacupé, Barrio Kennedy, 25 Jan 1987 (P, fr), E. Bordas 4090 (CTES); idem, camino de Caacupé a Tobaty, 3 Feb 1978 (P, fr), A. Schinini 14594 (CTES); idem, $8 \mathrm{Km}$ del pueblo, en bosque, 20 May 1975 (P, fr), P. Arenas 11232 (CTES); idem, San Bernardino, lomada, Jan 1968 (P, fl), A. Schinini 2083 (CTES); idem, Cerrito San Bernardino, orillas de montes, Oct 1915 (S, fl), E. Hassler 1527 (SI); idem, Aug 1915 (fl, S), E. Hassler 
339 (SI); idem, Aug 1915 (S, fl), E. Hassler 323 (SI), idem, Oct 1915, E. Hassler 323 (SI); idem, Costa del Lago Ypacaray, 14 Oct 1973, C. Quarín et al. 1571 (CTES); idem, Aug 1901-1902, E. Hassler 3111 (G00229777). - ÑNeEmbuCu, Distrito de Guazú-cuá, Estancia de Amancio Santa Cruz, 26 $58^{\prime} 46.4^{\prime \prime} \mathrm{S}$ 57²48'15.8”W, 31 Aug 2004 (P, fl). C. Vogt 175 (CTES); idem, Humaitá, bosque Ribera del Río Paraguay, 12 Dec 1950 (P, fr), A. G. Schulz 7744 (CTES). -PARAguart: Pirayú, Cerro, ca. $280 \mathrm{~m}$, R. Duré 125 (CTES); idem, 9 Feb 1983 (P, fr), L. Pérez de Molas 124 (CTES); Cordillea de Ybytyruzú, Cerro Peró, $1 \mathrm{Km} \mathrm{W}$ of Destacamento Tororo, forest on western side of Cerro Peró, 255'ㄱ, 56 ${ }^{\circ} 15^{\prime} \mathrm{W}, 13$ Jan 1989 (P, fr), E. Zardini \& A. Aguayo 9530 (FCQ, MO); Paraguarí, Costa II, Cerro Palacios, 29 Jan 1988 (P, fr), I. Basualdo 1344 (MO). - Presidente Hayes: Estancia Santa Asunción, $23^{\circ} 54^{\prime} 39^{\prime \prime} \mathrm{S}, 58^{\circ} 34^{\prime} 49^{\prime \prime} \mathrm{W}, 12 \mathrm{Feb} 2004$ (P, fr), J. De Egea \& M. Peña Chocarro 237

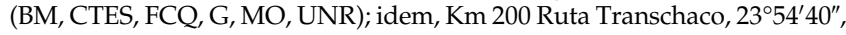

58³4'50", 12 Oct 2003 (P, fr), M. Peña-Chocarro 1466 (BM, MO, FCQ); idem,

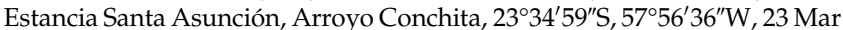
1995 (P, fr), R. Degen \& F. Mereles 3253 (CTES, FCQ); idem, Estancia N, $24^{\circ} 16^{\prime} 47^{\prime \prime} \mathrm{S}, 58^{\circ} 33^{\prime} 18^{\prime \prime} \mathrm{W}, 1 \mathrm{Feb} 2005$ (P, fr), J. De Egea \& M. Peña Chocarro 756 (BM, FCQ, MO); Ruta Concepción - Pozo Colorado, Estancia Loma Porá, a $5 \mathrm{Km}$ del casco de la Estancia, en bosque, 8 Jun 1995 (P, fr), R. Degen \& F. Mereles 3324 (FCQ, MO); Pozo Colorado, en las cercanías, bosque de Schinosis balansae, 15 Apr 1994 (P, fr), F. Mereles \& R. Degen 5539 (FCQ, MO). - SAN PEDRO: Estancia Serratom a $1000 \mathrm{~m}$ del casco de la Estancia, orillas de bosques, Sep 1992 (S, fl), N. Soria 5298 (FCQ, MO).

In total, there are five species of Randia in the Southern Cone of America: $R$. brevituba, $R$. calycina, R. ferox, R. micracantha, and the new $R$. heteromera (Fig. 3). A key to distinguish these species of Randia is presented below, including the morphological and anatomical characteristics.

\section{Key to Distinguish Randia heteromera from the Remaining Species of the Southern Cone of America}

1. Branches with more than two whorls of spines, each followed by a macroblast or a brachyblast; the spines thin, acicular and breakable; corolla infundibuliform, yellow-green or yellow; pollen grains with reticulate exine . . . . . . . . . . . . . . . . . . . . Randia micracantha

1. Branches with a subapical whorl of spines followed by one or more brachyblasts, the spines mostly robust; corolla salverform, white later becoming

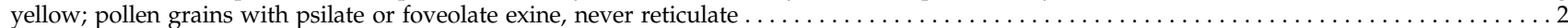
2. Plants (2-)4-12 m tall; corolla tube 22-34 (S), 25-27 (P) mm long; fruit 30-50 × 25-30 mm; pericarp 1.2-3.5 mm thick, ligneous ... Randia ferox 2. Plants $0.8-4(-6) \mathrm{m}$ tall; corolla tube $2.8-16.1(\mathrm{~S}), 4.7-16(\mathrm{P}) \mathrm{mm}$ long; fruit $13-30(-35) \times 12-19 \mathrm{~mm}$, pericarp $0.3-1 \mathrm{~mm}$ thick, coriaceous . . . 3

3. Leaf blades pubescent or hispid, rarely the adaxial face glabrous; calyx and external surface of corolla pubescent, rarely puberulous; pollen grains with psilate to foveolate exine; fruit puberulous, with numerous lenticels at maturity . . . . . . . . . . . . . . . Randia calycina

3. Leaf blade glabrous or puberulous on both faces; calyx and external surface of corolla glabrous; fruit glabrous, without lenticels ..... . . . 4 4. Leaf with domatia; calyx lobes externally glabrous, internally pubescent, margin glabrous or puberulous; corolla tube $4.7-5.4$ (P) and $2.8-7.9$ (S) $\mathrm{mm}$ long; pollen with psilate exine; fruit sessile or subsessile, $13-17.2 \mathrm{~mm}$ long . . . . . . . . . . . . . . . . Randia brevituba 4. Leaf without domatia; calyx lobes glabrous externeally and internally, margin conspicuously ciliate, corolla tube 10.5-14.4 (P) and 11.5-14.7 (S) $\mathrm{mm}$ long; pollen with psilate to foveolate exine; fruit pedicellate, $22-27.2 \mathrm{~mm}$ long . . . . . . . . . . . . . Randia heteromera

Anatomical Studies-A histological study of the leaf, petiole, stipules, and stipular colleters was performed in $R$. heteromera and, for comparison, on the leaf of R. brevituba that had not been studied before.

\section{Randia heteromera}

LEAF BLADE-In surface view, both epidermises have polygonal cells with straight to slightly sinuous walls (Fig. 4A-B); the paracytic stomata are restricted to the lower surface (Fig. 4B), with a density of $330 / \mathrm{mm}^{2}$. Trichomes are mainly restricted to the abaxial surface of the veins; they are nonglandular, unicellular, with lignified walls (Fig. 4C).

In cross section the cells of the adaxial epidermis are square to rectangular, and the cells of the abaxial epidermis are rounded to ovoid. The mesophyll is dorsiventral with a 3-4layer palisade parenchyma, and a 4-5-layer spongy parenchyma with reduced lacunar spaces (Fig. 4D). Idioblasts containing druses of calcium oxalate are distributed throughout the mesophyll (Fig. 4D-E); the larger ones are located between the palisade parenchyma cells. The vascular bundles are of the collateral type, surrounded by a parenchymatous bundle sheath (Fig. 4F). The leaf margin has thicker cuticle and collenchyma (Fig. 4G).

The middle vein is slightly protruding on the adaxial face of the leaf blade and prominent on the abaxial face. The vascular system is formed of an ectophloic siphonostele with two dorsal accessory vascular bundles (Fig. $4 \mathrm{H})$. Fibers are present in the bundle sheaths (Fig. 4I). Angular collenchyma (Fig. 4J) is present on both faces of the middle vein. Little druses are distributed in the siphonostele and in the surrounding parenchyma.

Petiole-The petioles are round at the base and winged towards the lamina, with the same features as found in the leaf blade. The petiole has a siphonostele from which two vascular bundles are detached in the distal portion; fibers are absent in the bundle sheath (Fig. 4K-L).

STIPULES-The mature stipules are green when fresh, triangular and mucronate (Fig. 5A). The inner surface is glabrous at the apex, the base of the stipule presents non-glandular trichomes and several colleters. The surface of the stipule has domes in the area where the largest druses are located (Fig. 5B-D). In cross section the epidermis is one-layered, covered by a thin cuticle (Fig. 5E-G). Stomata were observed on the outside at the same level or slightly higher than the surrounding epidermal cells (Fig. 5E). The mesophyll is homogeneous, compact, and it presents druses of different sizes. Collateral vascular bundles are present at the base of the stipules (Fig. 5E). They are surrounded by fibers at the middle of the stipules (Fig. 5F), and there are packages of fibers at the apex of the stipules (Fig. 5G). The secretion produced by the colleters accumulates inside the stipule (Fig. 5G).

Colleters (FIG. 5H-M)-Several colleters of the standard type occur at the base of the inner face of the stipules. They are green in fresh stipules and have a conical shape with a basal constriction (Fig. 5H), the size is $432-786 \times 110-144 \mu \mathrm{m}$. Structurally, these colleters are formed by a core of chlorenchyma surrounded by a compact, one-layered, secretory epidermis and covered by a thin cuticle (Fig. 5I). The chlorenchyma core is multi-layered, with the cells arranged perpendicularly to the epidermis, without any intercellular spaces. No vascular tissue or druses were found.

In young stipules, colleters at different stages of maturity can be found. The primordial cells (protoderm and underlying meristem) are recognisable because they have dense cytoplasm. The formation of a colleter starts when some cells of the protoderm elongate and divide anticlinally, while those of the ground meristem have periclinal and anticlinal divisions. Consequently, a small projection is formed (Fig. 5J). This projection is lengthened by successive divisions and cell expansion (Fig. 5K-M). The cells of the ground meristem elongate axially and form the chlorenchyma core, and the cells of the protoderm elongate anticlinally and form the secretory epidermis, resulting in the fully developed colleter. 

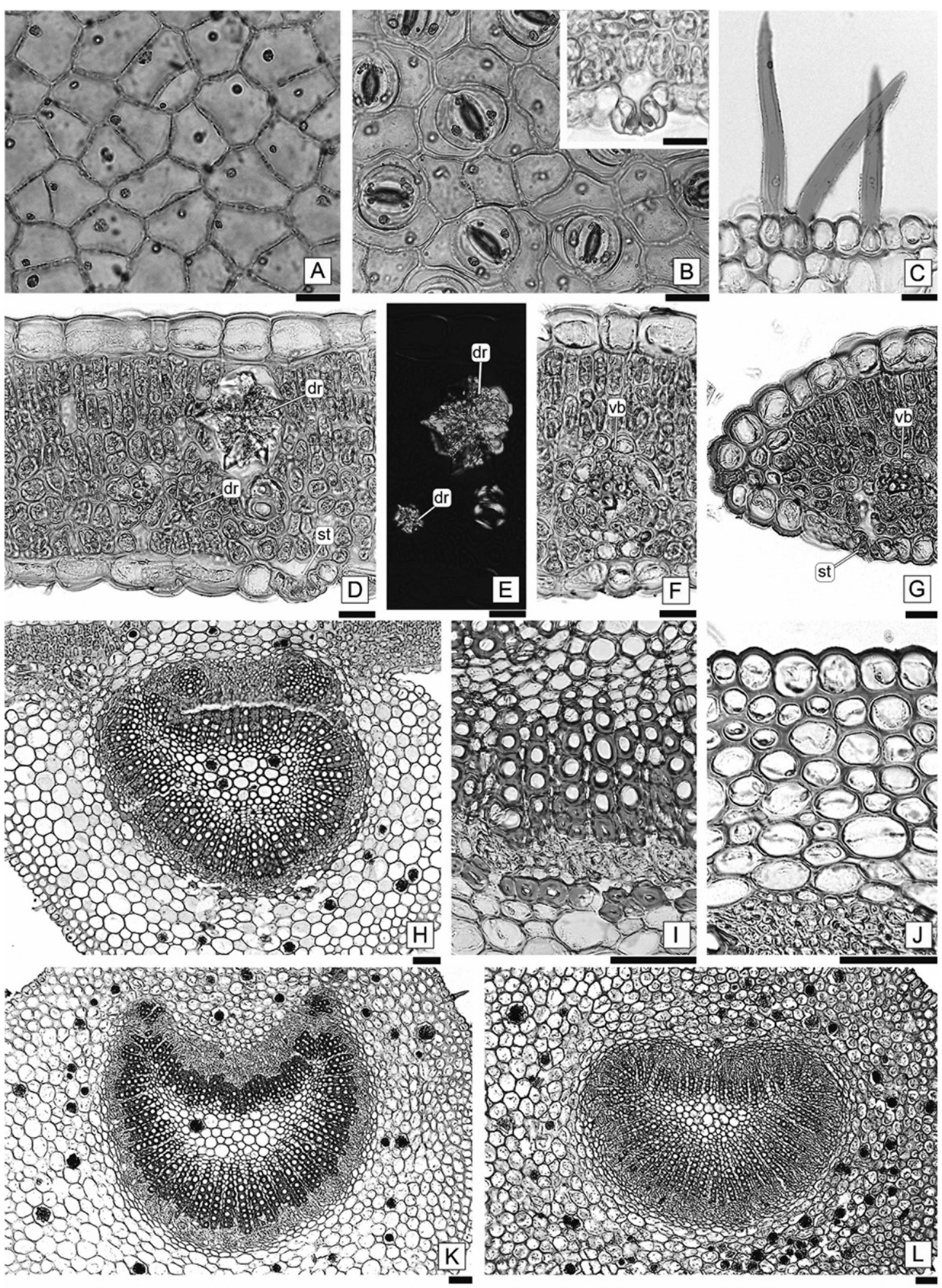

FIG. 4. Leaf anatomy of Randia heteromera (LM). A. Upper epidermis. B. Lower epidermis with stomata; above, detail of stoma in longitudinal section. C. Trichomes on the abaxial surface of the middle vein. D. Cross section of the leaf blade. E. Druses with polarized light. F. Vascular bundle of the leaf blade. G. Margin of the leaf blade. H. Middle vein. I. Detail of the vascular tissue and fibers. J. Collenchyma of the middle vein. K. Portion of the petiole adjacent to the leaf blade. L. Portion of the petiole adjacent to the stem. Abbreviations: $\mathrm{dr}=$ druse; st $=$ stoma; $v b=$ vascular bundle. $\mathrm{Scales}: \mathrm{A}-\mathrm{G}=20 \mu \mathrm{m} ; \mathrm{H}-\mathrm{L}=50 \mu \mathrm{m}$.

Randia brevituba

LEAF BLADE-In surface view, both epidermises have polygonal cells with straight to slightly sinuous walls (Fig. 6A-B). Stomata are present mainly on the lower surface of the leaf blade, with a density of $164 / \mathrm{mm}^{2}$ (Fig. 6B); in addition, there may occasionally be some on the upper epidermis of the veins. The mesophyll consists of a 1-2-layered palisade parenchyma and a 5-6-layered spongy parenchyma (Fig. 6D). Idioblasts with druses are distributed throughout the mesophyll, the largest ones are restricted to the palisade parenchyma. The 

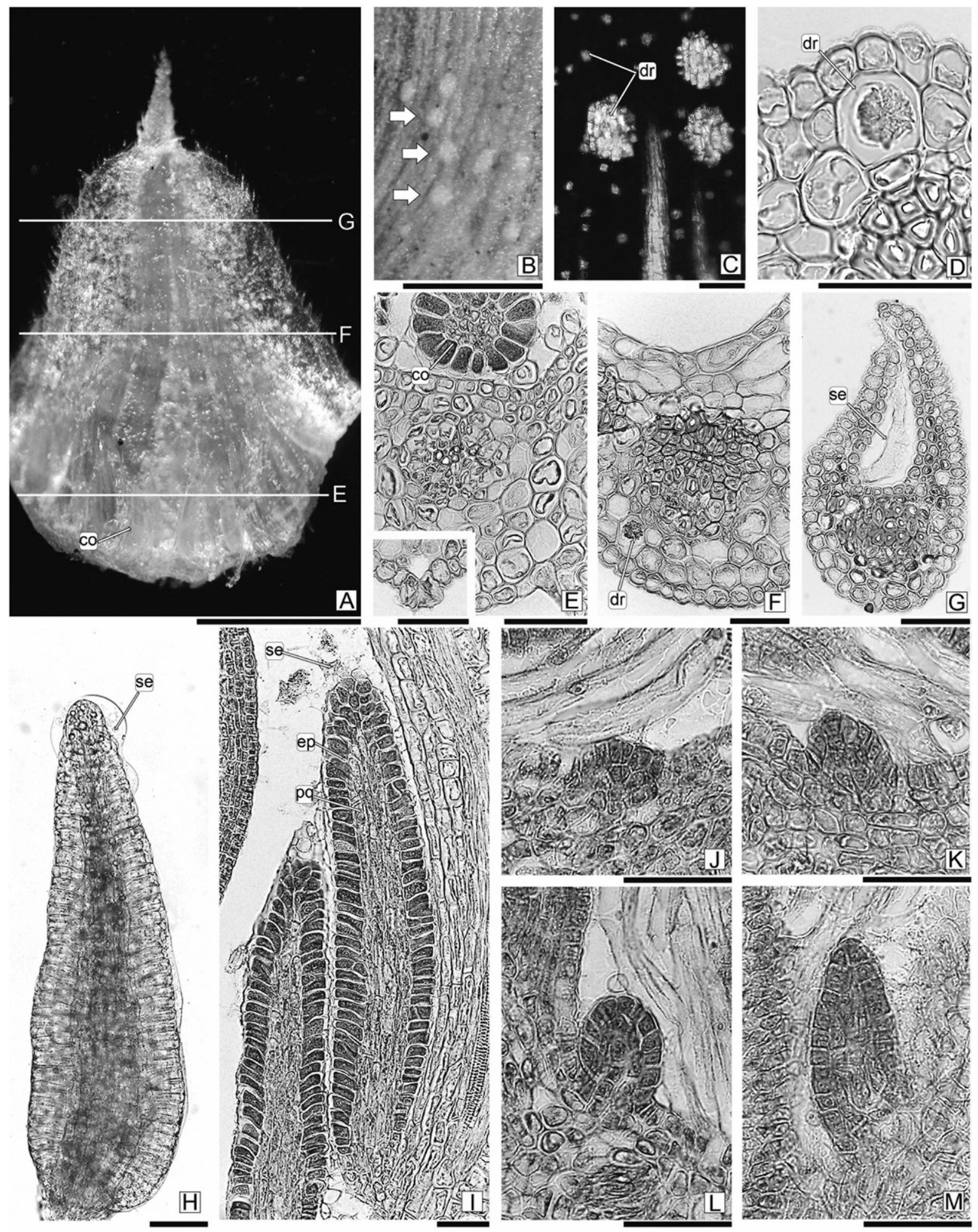

FIG. 5. Stipule and colleters of Randia heteromera. A. Inner surface of fresh stipule. B. Detail of the external surface of the stipule showing the domes (arrows) formed by the druses. C. Portion of the stipule observed with polarized light; druses of different sizes are visible. D. Detail of a druse. E-G. Cross section of stipule at different levels. E. Base with vascular bundle and colleter; below, detail of stoma. F. Middle portion with vascular bundle and fibers. G. Apex with fibers, note the secretion accumulated by the colleters. H. Fresh colleter with secretion. I. Longitudinal section of mature colleters. J-M. Different stages of development of the colleter. Abbreviations: $\mathrm{co}=$ colleter; $\mathrm{dr}=$ druse; $\mathrm{ep}=$ epidermis; $\mathrm{pq}=$ parenchyma; $\mathrm{se}=$ secretion. Scales: $\mathrm{A}=1 \mathrm{~mm} ; \mathrm{B}=0.5 \mathrm{~mm} ; \mathrm{C}-\mathrm{M}=50 \mu \mathrm{m}$.

vascular bundles are of the collateral type, surrounded by a parenchymatous sheath.

The middle vein is slightly protruding on the adaxial face of the leaf blade and prominent on the abaxial face. The vascular system is an ectophloic siphonostele with a dorsal bundle, surrounded by fibers (Fig. 6E). Angular collenchyma is present on both faces of the vein, occasionally interrupted by chlorenchyma on the adaxial face. The epidermis in this zone has an elevated stoma with a small substomatic chamber (Fig. 6C, E). 
The main anatomical features of the species of Randia in the Southern Cone of America are summarized in Table 1.

\section{Discussion}

Taxonomy-Randia specimens are difficult to identify, especially when they only bear staminate flowers (sometimes without a corolla) or fruits. Additionally, most herbarium specimens are misidentified and often several species are classified under the same name, as already suggested in previous studies (Judkevich et al. 2015, 2016). In our opinion, studies on the genus need seasonal observation of the plants in order to obtain both staminate and pistillate individuals. Moreover, when possible it is necessary to perform multidisciplinary studies to find the diagnostic features that support specific concepts in Randia. In the present study the leaf anatomy represented a useful and complementary tool to the classical taxonomic studies, which together served to determine the new species Randia heteromera.

Vegetative Reproduction-It was observed that plants of Randia heteromera have asexual reproduction with rhizomes. In angiosperms in general, vegetative propagation can occur under natural conditions with stolons or rhizomes, representing an effective strategy when sexual reproduction conditions are difficult in ecosystems with some type of stress (Cambronero and Stéfano 2006). When threats occur, they can form independent units called ramets (Alpert 1996).

Vegetative reproduction is an ecological characteristic commonly associated with dioecious plants, composed of two sexual morphotypes, implying dependence on pollen vectors for sexual reproduction (Benevides et al. 2015). However, vegetative propagation has also been described in other arboreal taxa of Rubiaceae that are hermaphrodites, e.g. Warszewiczia uxpanapensis (Lorence) C.M.Taylor (tribe Rondeletieae), a species with vegetative propagation by regrowth of branches or fallen trunks, and even branches attached to trees that produce adventitious roots (Cambronero and Stéfano 2006). In addition, the presence of rhizomes has been described in the genus Larsenaikia Tirveng. of the tribe Gardenieae (Tirvengadum 1993). Further field observations should be made to determine whether vegetative propagation by rhizomes is a characteristic of other species in the genus Randia.

Anatomy of the Leaf Blade and the Petiole-In the Rubiaceae, the leaves are commonly hypostomatic with paracytic stomata, dorsiventral mesophyll, and collateral vascular
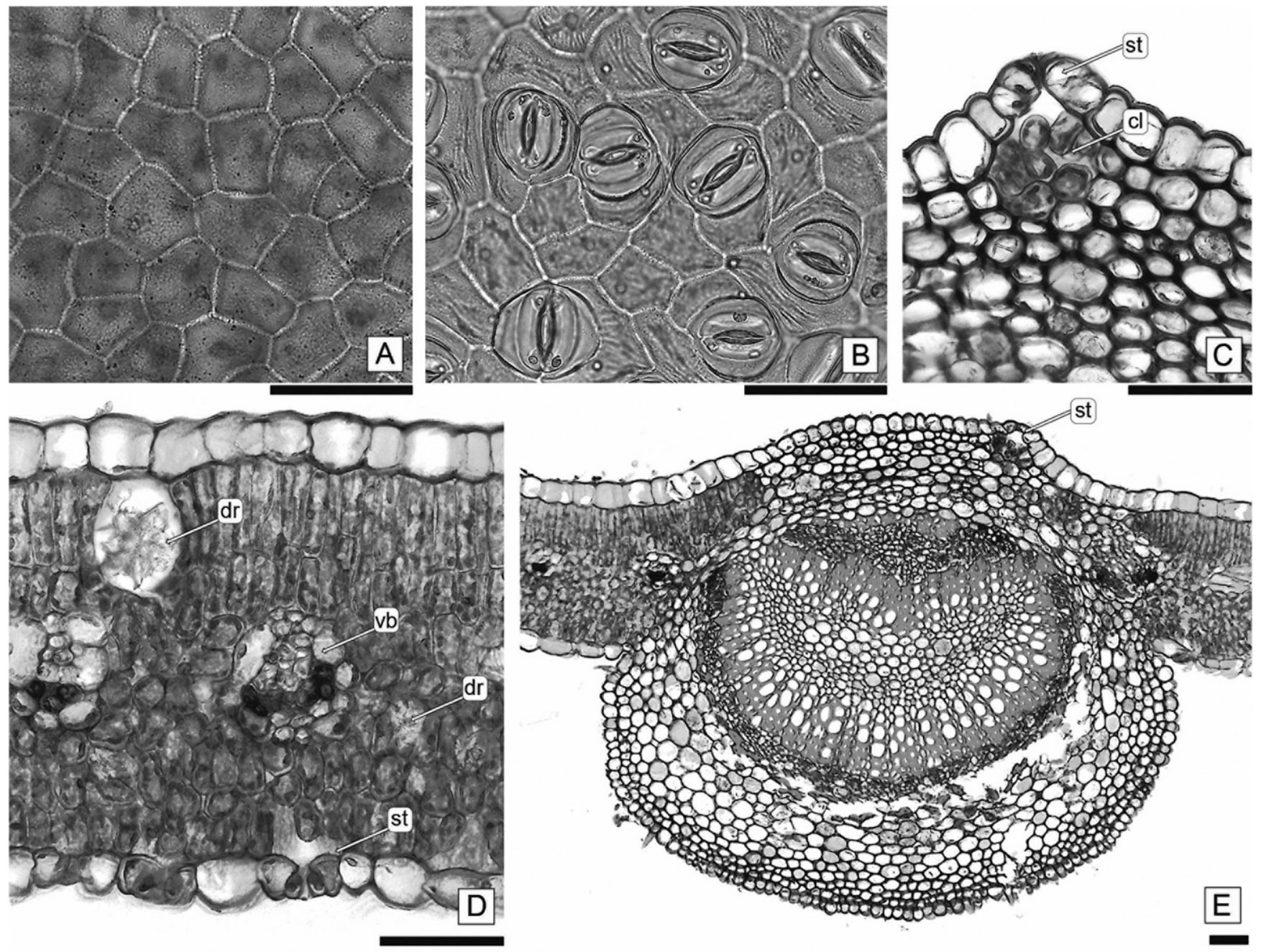

FIG. 6. Leaf anatomy of Randia brevituba (LM). A. Upper epidermis. B. Lower epidermis with stomata. C. Detail of a stoma the lower epidermis of the middle vein, note the underlying chlorenchyma. D. Cross section of the leaf blade. E. Middle vein. Abbreviations: $\mathrm{cl}=\mathrm{chlorenchyma;} \mathrm{dr}=\mathrm{druse} ; \mathrm{st}=\mathrm{stoma}$; $\mathrm{vb}=$ vascular bundle. Scales: $50 \mu \mathrm{m}$ 
bundles (Metcalfe and Chalk 1950; Brouwer and Clifford 1990; Martínez-Cabrera et al. 2009). Randia heteromera shares these general characteristics with the other species of Randia in the southern cone of America (Judkevich et al. 2015). In addition, a particular feature was found in R. brevituba, notably that the middle vein of the foliar lamina presents adaxial stomata and the collenchyma in this zone is interrupted by chlorenchyma.

The organization of the vascular system in the middle vein of the leaf blade and in the petiole has taxonomic significance (Metcalfe and Chalk 1950; Kocsis and Borhidi 2003a, b; Arruda et al. 2010; Kocsis et al. 2004; Teixeira et al. 2016). In some cases, families, genera, species, or varieties can be distinguished by the superficial characters and vascular arrangement of the leaf (Kocsis and Borhidi 2003a). In Rubiaceae there are several studies that demonstrate the taxonomic value of foliar anatomical characters at different hierarchical levels. Kocsis and Borhidi (2003b) studied the anatomy of the petiole in species of three neotropical genera of Rubiaceae, Rondeletia L., Javorkaea Borhidi \& Járai-Koml., and Rogiera Planch. They concluded that the petiole anatomy can be used as a character to distinguish between these three genera. Also, in Psychotria spp., Moraes et al. (2011) concluded that the anatomy of the leaf blade could be used as a diagnostic feature in the genus.

The data collected here, and in previous studies (Judkevich et al. 2015, 2016), show that $R$. brevituba, R. calycina, R. ferox, $R$. heteromera, and $R$. micracantha can be differentiated by the vascular system in their leaves, which is important when there is no material other than the vegetative (Fig. 7). MartínezCabrera et al. (2009) studied the leaf and petiole anatomy of 36 species of Rubiaceae in which vascular tissue variation was classified into five types: type I, simple arc; type II, arc with invaginated ends and a pair of lateral bundles; type III, arc with slightly curved ends and a pair of lateral bundles; type IV, $\mathrm{V}$-shaped open arc with invaginated ends and four to six lateral bundles below or between the invaginated ends; and type $\mathrm{V}$, closing ring. According to this classification (which is the only one proposed for the family), Randia micracantha belongs to type I and R. ferox to type V. However the other Randia species analyzed differ from these five types, so it is suggested that the following new types be considered: type VI, siphonostele with a dorsal vascular bundle and fibers (in Randia brevituba); type VII, siphonostele with a dorsal vascular bundle, without fibers (in R. calycina); and type VIII, siphonostele with two dorsal vascular bundles and fibers (in R. heteromera).

Stipule and Colleters-Few anatomical studies have been performed on the stipules of the Rubiaceae (Robbrecht 1988).
The stipular anatomy of Randia had never been described before. On the surface of the stipule of $R$. heteromera, small domes are observed that coincide internally with the presence of druses. This observation was also made in leaves, petioles, and stipules of Preussiodora sulphurea (K.Schum.) Keay (Gardenieae), in which the druses have a diameter of 50-100 $\mu \mathrm{m}$ (Robbrecht 1978). Anatomically, R. heteromera has stipules characterized by an epidermis covered with a thin cuticle, abaxial paracytic stomata, homogeneous mesophyll with druses of different sizes, and collateral vascular bundles, in some cases surrounded by fibers. The homogeneous mesophyll with collateral vascular bundles has also been mentioned for the stipules of Psychotria velloziana Benth. (tribe Psychotrieae, Da Cunha and Vieira 1993/1997) and Psychotria viridis Ruiz \& Pav. (Quinteiro et al. 2006).

According to recent studies carried out in the Rubiaceae, the colleters in this family can be found in the calyx (in the interlobular sinus, on the margin of the lobes and at the base of the internal face of the lobes), bracteoles, stipules (on the margin and internal face), and even on reduced laciniae on underground buds (Judkevich et al. 2017). In Randia, the colleters are distributed on the inner surface at the base of the stipule. This distribution is also common in Bathysa stipulata (Vell.) C.Presl, B. gymnocarpa K.Schum. (lacrymiform type, tribe Condamineeae, Castro Miguel et al. 2010), and B. cuspidata (A.St.-Hil.) Hook.f. (standard type, Coelho et al. 2013), Gardenia lucida Roxb. (standard type, tribe Gardenieae, Dave et al. 1988), Preussiodora sulphurea (standard type, tribe Gardenieae, Robbrecht 1978), Psychotria nuda (Cham. \& Schltdl.) Wawra (lacrymiform type, tribe Psychotrieae, Castro Miguel et al. 2009), and Robbrechtia spp. (standard, tribe Pavetteae, De Block 2003). According to Robbrecht (1988), the distribution of colleters on the internal surface of stipules may be the primitive condition.

The absence of colleters in the calyx of Randia has been mentioned previously by Gustafsson (1998) who used this morphological character, among others (unisexual flowers and branches with thorns), to distinguish it from Rosenbergiodendron Fagerl. (branches without thorns and hermaphrodite flowers), which was considered a synonym of Randia until then.

Taking into account their morpho-anatomy, the stipular colleters of Randia heteromera belong to the standard type according to the classification of Lersten (1974a, 1974b) for the Rubiaceae, the same type as found in the other species of Randia (Judkevich et al. 2015). Their ontogeny demonstrates that these secretory structures are emergences (Hallé 1967; Dave et al. 1988; Thomas 1991; Coelho et al. 2013; Muravnik et al. 2014; Judkevich et al. 2017).

TABLE 1. Main anatomical features of the species of Randia in the Southern Cone of America. Abbreviations: dvb $=$ dorsal vascular bundle; $\mathrm{fi}=\mathrm{fibers}$; $\mathrm{pp}$ = palisade parenchyma; $\mathrm{si}=$ siphonostele; spo = spongy parenchyma; $\mathrm{svb}=$ semilunar vascular bundle.

\begin{tabular}{|c|c|c|c|c|c|c|}
\hline Species & Middle vein of the leaf & Stoma position of the leaf & Stoma density of the leaf & Mesophyll of the leaf & Colleter type & Reference \\
\hline R. brevituba & $\mathrm{Si}+1 \mathrm{dvb}+\mathrm{fi}$ & Abaxial, some adaxial in the vein & $167 / \mathrm{mm}^{2}$ & $\begin{array}{l}\text { 1-2 layer pp } \\
\text { 5-6 layer spo }\end{array}$ & Standard & Judkevich et al. 2016 \\
\hline R. calycina & $\mathrm{Si}+1 \mathrm{dvb}$ & Abaxial & $335 / \mathrm{mm}^{2}$ & $\begin{array}{l}\text { 3-4 layer pp } \\
4-6 \text { layer spo }\end{array}$ & Standard & Judkevich et al. 2015 \\
\hline R. ferox & $\mathrm{Si}$ & Abaxial & $147 / \mathrm{mm}^{2}$ & $\begin{array}{l}\text { 1-2 layer pp } \\
5-6 \text { layer spo }\end{array}$ & Standard & Judkevich et al. 2015 \\
\hline R. heteromera & $S i+2 d v b+f i$ & Abaxial & $330 / \mathrm{mm}^{2}$ & $\begin{array}{l}3-4 \text { layer pp } \\
4-5 \text { layer spo }\end{array}$ & Standard & Present paper \\
\hline R. micracantha & Svb & Abaxial & $67 / \mathrm{mm}^{2}$ & $\begin{array}{l}1-2 \text { layer pp } \\
4-5 \text { layer spo }\end{array}$ & Standard & Judkevich et al. 2015 \\
\hline
\end{tabular}




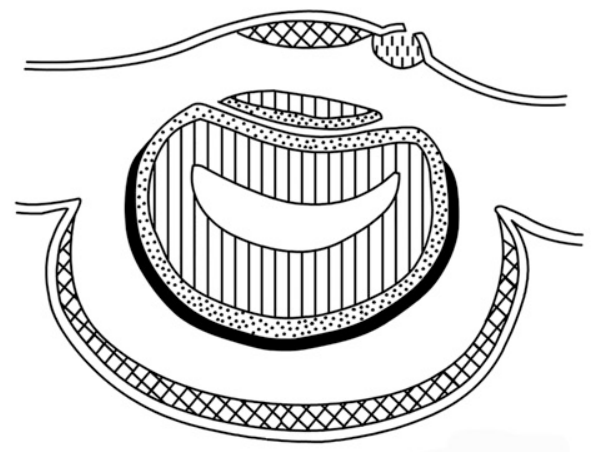

A
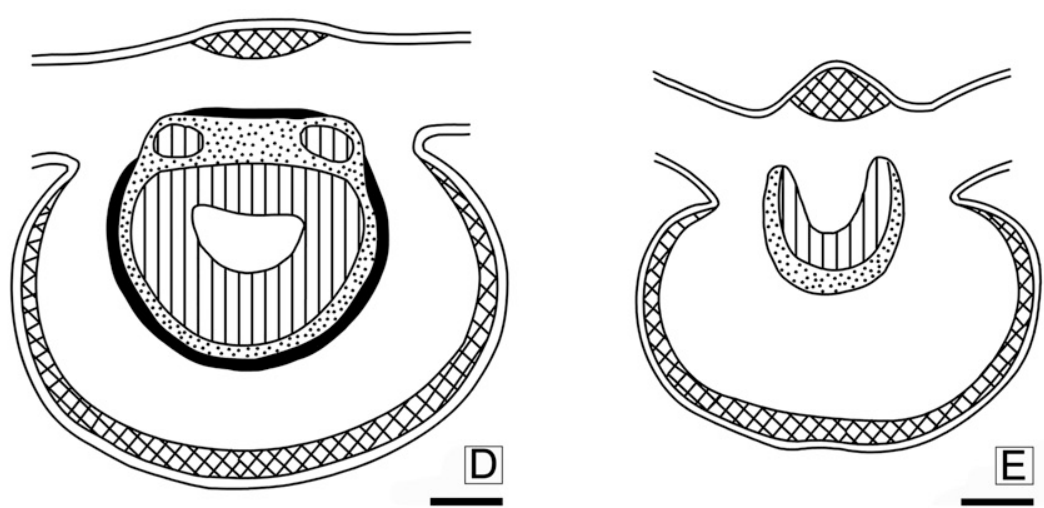
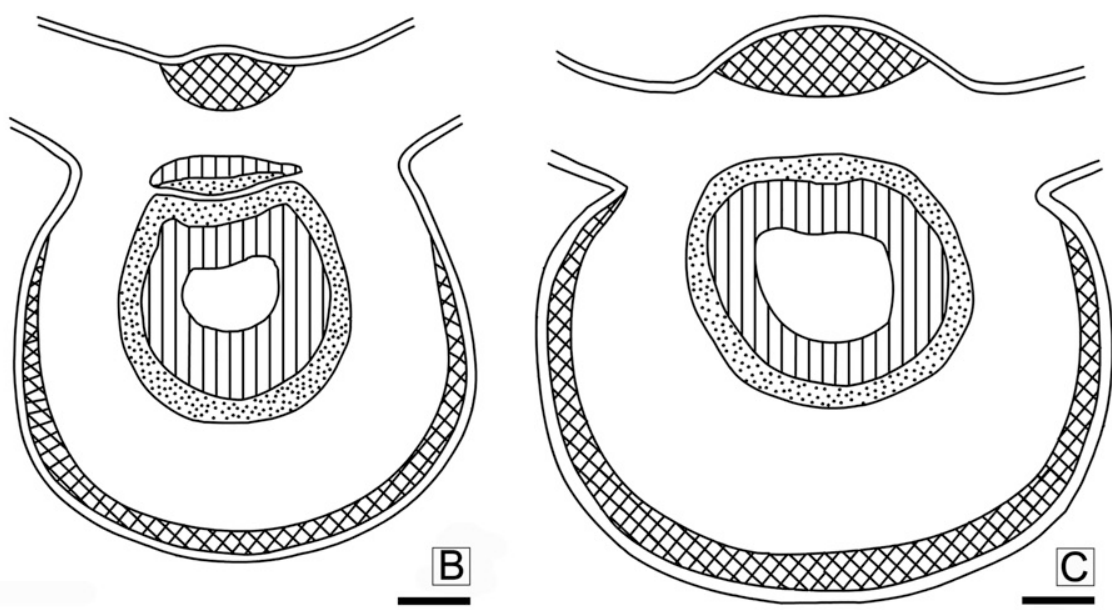

FIG. 7. Diagrams of the middle veins of Randia spp. of the Southern Cone of America. A. R. brevituba, middle vein with siphonostele and a dorsal vascular bundle, with fibers. B. R. calycina, middle vein with siphonostele and a dorsal vascular bundle, without fibers. C. $R$. ferox, middle vein with siphonostele, without accessory vascular bundles. D. R. heteromera, middle vein with siphonostele, two dorsal vascular bundles, and fibers. E. $R$. micracantha, middle vein of the leaf blade with a semilunar bundle.

Recently, green stipular colleters have been mentioned in other species of the tribe Gardenieae, such as Cordiera concolor (Cham.) Kuntze, C. sessilis (Vell.) Kuntze, Tocoyena formosa (Cham. \& Schltdl.) K., and Randia sp. (Tresmondi et al. 2015). This type of colleter has also been found in several species of the tribe Spermacoceae (Rubiaceae, Judkevich et al. 2017), and in the Gentianaceae Macrocarpaea obtusifolia (Griseb.) Gilg. (Dalvi et al. 2014).

The presence of the standard colleters on the inner surface of the stipules seems to be a constant feature for the genus Randia.

Randia is a genus taxonomically still poorly known and its species have undergone several taxonomic rearrangements. It is necessary to explore the genus through different disciplines that are complementary to classical taxonomy. The present study shows that vegetative anatomy can provide useful characters to distinguish between the species of Randia, at least in the Southern Cone of America.

\section{ACKNOWLEDGMENTS}

The first author thanks CONICET for the doctoral grant. This work was funded by PICTO 199-2011, PI 01-2012, PI A013-2013, PI 16P001, and PICT 2016-3517. We thank all herbarium curators cited for allowing us to examinspecimens, and especially MO curator, J. Solomon, for sending in loan and as gift plant material to CTES, and the curator and staff of $\mathrm{G}$ herbarium for sending images of all specimens cited by Emile Hassler in Plantae Hasslerinae. We also thank Charlotte Taylor for useful suggestions on genus Randia.

\section{Author Contributions}

MDJ and RMS collected the plant material, analyzed it, and made the taxonomic description. RMS provided the field photos and distribution map. MDJ processed the plant material to make the histological preparations, took the microscopy photos and prepared the figures and drawings, being supervised by AMG. MDJ and AMG performed the anatomical interpretations. MDJ, AMG, and RMS contributed in the discussions and approved the final manuscript.

\section{Literature Cited}

Alpert, A. 1996. Nutrient sharing in natural clonal fragments of Fragaria chiloensis. Journal of Ecology 84: 395-406.

Arruda, R. C. O., D. M. S. Gomes, A. C. Azevedo, M. L. Magalhães, and M. Gomes. 2010. Leaf anatomy and micromorphology of six Posoqueria Aublet species (Rubiaceae). Rodriguésia 61: 505-518.

Bacigalupo, N. M., E. L. Cabral, and C. M. Taylor. 2008. Rubiaceae. Pp. 2871-2920 in Catálogo de Plantas Vasculares del Cono Sur, vol. 3, Monographs in Systematic Botany from the Missouri Botanical Garden 107, eds. F. O. Zuloaga, O. Morrone, and M. J. Belgrano. Saint Louis: Missouri Botanical Garden.

Benevides, C. R., A. T. A. Rodarte, and H. A. de Lima. 2015. Vegetative propagation as a successful reproductive strategy in woody dioecious species in tropical coastal vegetation, southeast Brazil. Brazilian Journal of Botany 38: 579-584.

Bernardi, L. 1985. Contribución a la dendrología paraguaya: Segunda parte. Boissiera 37: 7-294.

Brouwer, Y. M. and H. T. Clifford. 1990. An annotated list of domatia bearing species. Notes from the Jodrell Laboratory 12: 1-33.

Cambronero, L. B. and J. F. Stéfano. 2006. Posible influencia de los rametes en la estructura poblacional y distribución del árbol gigante 
Warszewiczia uxpanapensis, Cordillera de Tilarán, Costa Rica. Revista de Biología Tropical 54: 1179-1188.

Carlquist, S. 1961. Comparative Plant Anatomy. New York: Holt, Rinehart and Winston.

Castro Miguel, E., D. Gomes de Moraes, and M. da Cunha. 2009. Stipular colleters in Psychotria nuda (Cham. \& Schltdl.) Wawra (Rubiaceae): Micromorphology, anatomy and cristals microanalysis. Acta Botanica Brasílica 23: 1034-1039.

Castro Miguel, E., D. Espellet Klein, M. A. Oliveira, and M. da Cunha. 2010. Ultrastructure of secretory and senescence phase in colleters of Bathysa gymnocarpa and B. stipulata (Rubiaceae). Revista Brasileira de Botanica. Brazilian Journal of Botany 33: 425-436.

Chodat, R. H. and E. Hassler. 1904. Plantae hasslerianae soit énumération des plantes récoltées au Paraguay par le Dr Emile Hassler de 1885-1902. Bulletin de l'Herbier Boissier 2: 169-196.

Coelho, V. P. M., J. P. V. Leite, L. G. Fietto, and M. C. Ventrella. 2013. Colleters in Bathysa cuspidata (Rubiaceae): Development, ultrastructure and chemical composition of the secretion. Flora 208: 579-590.

Da Cunha, M. and R. C. Vieira. 1993/1997. Anatomia foliar de Psychotria velloziana Benth. (Rubiaceae). Rodriguésia 45/49: 39-50.

Dalvi, V. C., L. S. Cardinelli, R. M. S. A. Meira, and A. A. Azevedo. 2014 Foliar colleters in Macrocarpaea obtusifolia (Gentianaceae): Anatomy, ontogeny, and secretion. Botany 92: 59-67.

Dave, Y., P. M. Kuriachen, and V. Thomas. 1988. Development, structure and senescence of colleters in Gardenia lucida Roxb. (Rubiaceae). Acta Societatis Botanicorum Poloniae 57: 3-7.

De Block, P. 2003. Robbrechtia, a new Rubiaceae genus from Madagascar. Systematic Botany 28: 145-156.

Degen, R. A. and R. J. B. Negrelle. 2014. Estructura poblacional, regeneración y producción potencial de cera de Copernicia alba Morong ex Morong \& Britton en tres sitios de la región del Chaco, Paraguay. Iheringia. Série Botânica 69: 277-284.

Delprete, P. G. 2010. Rubiaceae. In Flora dos Estados de Goiás e Tocantins: Rubiaceae, vol. 40, ed. J. A. Rizzo. PRPPG/UFG e IRD, Goiânia.

Delprete, P. G., L. B. Smith, and R. M. Klein. 2005. Rubiáceas. In: Flora Ilustrada Catarinensis, vol. 2, ed. A. Reis. Itajaí: Herbário Barbosa Rodrigues.

Dickison, W. C. 1975. The bases of angiosperm phylogeny: Vegetative anatomy. Annals of the Missouri Botanical Garden 62: 590-620.

Erdtman, C. 1966. Pollen Morphology and Plant Taxonomy: Angiosperms (An Introduction to Palynology), revised edition. New York and London: Hafner Publishing Co.

Ferreira M. Jr. and A. O. Santos Vieira. 2015. Espécies arbóreo-arbustivas da família Rubiaceae Juss. na bacia do rio Tibagi, PR, Brasil. Hoehnea 42: 289-336.

Gonzalez, A. M. and C. L. Cristóbal. 1997. Anatomía y ontogenia de semillas de Helicteres lhotzkyana (Sterculiaceae). Bonplandia 9: 287-294.

Gustafsson, C. 1998. The Neotropical Rosenbergiodendron (Rubiaceae, Gardenieae). Brittonia 50: 452-466.

Gustafsson, C. 2000. Three new species of South American Randia (Gardenieae, Rubiaceae). Novon 10: 201-208.

Hallé, F. 1967. Étude biologique et morphologique de la tribu des Gardéniées (Rubiacées). Mémoires ORSTOM [Office de la recherche scientifique et technique Outre-Mer.] 22: 1-146.

Johansen, D. A. 1940. Plant Microtechnique. San Francisco: McGraw-Hill.

Judkevich, M. D., R. M. Salas, and A. M. Gonzalez. 2015. Revisión de Randia (Rubiaceae) en Argentina, taxonomía y morfoanatomía. Boletín de la Sociedad Argentina de Botánica 50: 607-625.

Judkevich, M. D., R. M. Salas, and H. Keller. 2016. Randia brevituba (Rubiaceae), a new species from the Southern Cone of America and comments on Randia armata. Systematic Botany 41: 238-244.

Judkevich, M. D., R. M. Salas, and A. M. Gonzalez. 2017. Colleters in American Spermacoceae genera (Rubiaceae), morphoanatomical and evolutionary aspects. International Journal of Plant Sciences 178: 378-397.

Jung-Mendaçoli, S. L. and E. A. Araujo. 2007. Randia L. Pp. 412-415 in Flora Fanerogâmica do Estado de São Paulo, vol. 5, eds. M. G. L. Wanderley, G. J. Shepherd, T. S. Melhem, and A. M. Giulietti. São Paulo: Instituto de Botânica.

Kocsis, M. and A. Borhidi. 2003a. Petiole anatomical studies of some Rondeletia L. species (Rubiaceae). Acta Botanica Hungarica 45: 339-343.

Kocsis, M. and A. Borhidi. 2003b. Petiole anatomy of some Rubiaceae genera. Acta Botanica Hungarica 45: 345-353.
Kocsis, M., J. Darók, and A. Borhidi. 2004. Comparative leaf anatomy and morphology of some neotropical Rondeletia (Rubiaceae) species. Plant Systematics and Evolution 248: 205-218.

Lersten, N. R. 1974a. Colleter morphology in Pavetta, Neorosea and Tricalysia (Rubiaceae) and its relationship to the bacterial leaf nodule symbiosis. Botanical Journal of the Linnean Society 69: 125-136.

Lersten, N. R. 1974b. Morphology and distribution of colleters and crystals in relation to the taxonomy and bacterial leaf nodule symbiosis of Psychotria (Rubiaceae). American Journal of Botany 61: 125-136.

Lorence, D. H. 1986. Glossostipula (Rubiaceae), a new genus from Mexico and Guatemala. Candollea 41: 453-461.

Luque, R., H. C. Sousa, and D. J. E. Kraus. 1996. Métodos de coloração de Roeser (1972)-modificado-e Kropp (1972) visando a substituição do azul de astra por azul de alcião 8 GS ou 8 GX. Acta Botanica Brasílica 10: 199-212.

Martínez-Cabrera, D., T. Terrazas, and H. Ochoterena. 2009. Foliar and petiole anatomy of tribe Hamelieae and other Rubiaceae. Annals of the Missouri Botanical Garden 96: 133-145.

Metcalfe, C. R. and L. Chalk. 1950. Anatomy of the Dicotyledons. Oxford, UK: Clarendon Press.

Metcalfe, C. R. and L. Chalk. 1979. Anatomy of the Dicotyledons: Systematic Anatomy of the Leaf and Stem, vol. 1, ed. 2. Oxford, UK: Clarendon Press.

Moraes, T. M. S., G. Rodrigues Rabelo, C. Ribeiro Alexandrino, S. J. Silva Neto, and M. da Cunha. 2011. Comparative leaf anatomy and micromorphology of Psychotria species (Rubiaceae) from the Atlantic Rainforest. Acta Botanica Brasílica 25: 178-190.

Morrone, J. J. 2017. Neotropical biogeography: Regionalization and evolution. Boca Raton: CRC Press.

Muravnik, L. E., O. V. Kostina, and A. L. Shavarda. 2014. Development structure and secretion compounds of stipule colleters in Pentas lanceolata (Rubiaceae). South African Journal of Botany 93: 27-36.

Prado, D. E. 1993. What is the Chaco vegetation in South America? II. A redefinition. Candollea 48: 615-629.

Punt, W. P., P. Hoen, S. Blackmore, and A. Le Thomas. 2007. Glossary of pollen spore terminology. Review of Palaeobotany and Palynology 143: $1-81$.

Quinteiro, M. M. C., D. C. Teixeira, M. G. Moraes, and J. G. Silva. 2006. Anatomia foliar de Psychotria viridis Ruiz \& Pav. (Rubiaceae). Revista Universidade Rural: Série Ciências da Vida, Seropédica, RJ. EDUR 26: 30-41.

Robbrecht, E. 1978. Some observations in Preussiodora Keay (African Rubiaceae, Gardenieae). Bulletin de la Société Royale de Botanique de Belgique 111: 3-9.

Robbrecht, E. 1988. Tropical woody Rubiaceae. Opera Botanica Belgica 1: $1-271$.

Serrano, M. and J. Terán. 1998. Identificación de Especies Vegetales en Chuquisaca. Sucre: PLAFOR, Intercooperación, Fundación Ceibo.

Schumann, K. 1889. Randia Houst. In Flora Brasiliensis, ed. C. F. P. von Martius. 6: 341-343.

Silva Neto, S. J. and R. S. Ávila Jr. 2007. Uma nova espécie de Randia (Rubiaceae, Gardenieae) para o Estado do Rio de Janeiro, Brasil. Rodriguésia 58: 739-742.

Smith, L. B. and R. J. Downs. 1956. Resumo preliminar das Rubiaceae de Santa Catarina. Sellowia (Itajaí) 7-8: 13-86.

Solereder, H. 1908. Systematic Anatomy of the Dicotyledons. Oxford: Claredon Press.

Taylor, C. M. and D. H. Lorence. 1993. On the status of Randia armata (Sw.) DC. (Rubiaceae: Gardenieae). Taxon 42: 865-867.

Teixeira, T. R., M. S. Pádua, and A. H. F. Castro. 2016. Leaf anatomy of Cordiera sessilis (Vell.) Kuntze (Rubiaceae). Acta Scientiarum. Biological Sciences 38: 355-364.

Thiers, B. 2020 [continuously updated]. Index Herbariorum: A global directory of public herbaria and associated staff. New York Botanical Garden's Virtual Herbarium. http://sweetgum.nybg.org/science/ih/.

Tirvengadum, D. D. 1993. Larsenaikia, a new genus of the Rubiaceae from Australia. Nordic Journal of Botany 13: 175-184.

Thomas, V. 1991. Structural, functional and phylogenetic aspects of the colleter. Annals of Botany 68: 287-305.

Tresmondi, F., A. Nogueira, E. Guimarães, and S. R. Machado. 2015. Morphology, secretion composition, and ecological aspects of stipular colleters in Rubiaceae species from tropical forest and savanna. Naturwissenschaften 102: 73. 